\title{
Thinking Styles of Understanding Creative Mathematical Problems in the Process of Solving Them
}

\section{Мисленнєві стилі розуміння творчих математичних задач у процесі їх розв'язування}

\section{Lidiia Moiseienko}

Dr. in Psychology, Professor, Ivano-Frankivsk National Technical University of Oil and Gas, Ivano-Frankivsk (Ukraine)

ORCID ID: https://orcid.org/0000-0001-9288-7355

Researcher ID: http://www.researcherid.com/rid/X-7506-2018

E-mail: Lmoyseyenko@i.ua

\section{Лідія Мойсеєнко}

Доктор психологічних наук, професор, Івано-Франківський національний технічний університет нафти і газу, м. Івано-Франківськ (Україна)

\section{Liubov Shehda}

Ph.D. in Physical and Mathematical Sciences, Assistant Professor, Ivano-Frankivsk National Technical University of Oil and Gas, Ivano-Frankivsk (Ukraine)

ORCID ID: https://orcid.org/0000-0003-4721-7832

Researcher ID: http://www.researcherid.com/rid/Z-2516-2019

E-mail: shegda.luba@gmail.com

\section{Любов Шегда}

Кандидат фізико-математичних наук, доцент, Івано-Франківський національний технічний університет нафти i газу, м. Івано-Франківськ (Україна)

Address for correspondence, e-mail: kpnu_lab_ps@ukr.net Copyright: (C) Moiseienko Lidiia, Shehda Liubov

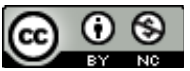
The article is licensed under CC BY-NC 4.0 International (https://creativecommons.org/licenses/by-nc/4.0/)

(C) Moiseienko Lidiia, Shehda Liubov

DOI (article): https://doi.org/10.32626/2227-6246.2021-51.142-164 http://journals.uran.ua/index.php/2227-6246 
DOI: https://doi.org/10.32626/2227-6246.2021-51

The author's contribution: Moiseienko L. $-60 \%$, Shehda L. $-40 \%$.

Авторський внесок: Мойсеєнко Л. $-60 \%$, Шегда Л. $-40 \%$.

\section{ABSTRACT}

The results of research of creative mathematical thinking are analyzed and the expediency of studying its individual differences through the analysis of mental styles of solving mathematical problems is stated.

The aim of the article is to identify thinking mathematical styles of students and to analyze the influence of style on the process of understanding the creative mathematical problem.

For identifying and determining the essence of mathematical thinking styles, the method of analysis of search actions of subjects during the solution of mathematical problems of different classes was used. The experiment involved 100 students of a technical university, 1000 processes for solving mathematical problems were analyzed.

The results of the research. It is stated that mental mathematical style is a holistic system of interconnected actions, by means of which the mental mathematical result is achieved, which distinguishes the activities of one person from another one.

The authors identify three thinking styles in creative mathematical process of students: the differential, the integral and the differential-integral. It is established that the thinking style is manifested during all processes micro-stages of understanding.

It is proved that the different thinking mathematical styles lead to the formation of different purports of the same problem.

It is established that unconscious mental guesses have different meanings in the process of understanding a mathematical problem by students with different styles of mathematical thinking.

Conclusions. Thinking mathematical style is manifested throughout the process of understanding a mathematical problem, provides a different content of the search process aimed at understanding a mathematical problem.

Key words: creative mathematical thinking, process of understanding, thinking mathematical styles.

(C) Moiseienko Lidiia \& Shehda Liubov

DOI (article): https://doi.org/10.32626/2227-6246.2021-51.142-164 


\section{Introduction}

Perceiving the growing importance of mathematics in the development of many areas of research (mathematics is the language of various sciences), we will focus on psychological research of creative mathematical thinking. On one hand, the unusualness of mathematical objects, their apparent difference from natural objects, creates the problem of their intersubjective status (Moreno-Armella, Hegedus \& Kaput, 2008). Therefore, obtaining reliable results, based on logical considerations, from abstract data encoded with certain symbols makes it possible to elucidate mechanisms of thinking action (Salomon, 1993). On the other hand, there is a need to study real thinking (not necessarily correct, as in logic) through the establishment of patterns of its flow (Zekeriya Karadag, 2009; Cengiz, Kline \& Grant, 2011).

The productive nature of thinking process is manifested in the fact that it goes infinitely far beyond the known situations. The reserves of the hidden features of human brain are not manifested in the formal application of previously acquired knowledge, but in the ability to choose arbitrarily the starting point of thinking, which is selected by the subject itself. This is why thinking often unfolds as a process of solving a new problem that involves irrelevant information (Rubinstein, 1958; Mumford \& Gustafson, 1988; Molyako, 2007; Yaftian, 2016). This requires the activation of various kinds of information, and the ability to use them to create beyond experience. This state of things was expressed by Ya. O. Ponomarev in his scientific position: "...thinking is always creative. It occurs in situations of problems which the subject does not have the means to solve». (Ponomarev, 1976: 194). Therefore, the study of creative mathematical thinking is based on the analysis of search for solutions to creative mathematical problems.

Relying on various features, the researchers divide the thinking process into species, types, etc. The allocation of practical and theoretical thinking (for example, Rubinstein, 1954; (C) Moiseienko Lidiia, Shehda Liubov

DOI (article): https://doi.org/10.32626/2227-6246.2021-51.142-164 
Teplov, 1961), of productive and reproductive (for example, Stepanov \& Semenov, 1981) types of thinking is quite common. A slightly different approach to the division of intellectual activity into types was proposed by V. O. Molyako (Molyako, 2007). This is a strategic-tactical approach. It consists in isolation in the intellectual activity of a holistic system that organizes and manages it throughout the creative process.

In general, in each searching thinking process the researchers distinguish procedural-dynamic and personal aspects. At the same time, in general process of creative thinking aimed at solving a problem, they conditionally distinguish the components: the process of understanding the problem, the process of constructing a solution project and the approbation process (Salomon, 1993; Molyako, 2007; Moiseienko, 2003; Fan \& Zhu, 2007). It is believed that a prerequisite for the success of any thinking process is understanding of the task to be accomplished (Molyako, 1983; Kovalenko, 1999). However, understanding of the problem is not an one-time act, it is formed in the solving process (Ziff, 1972; Mayer \& Hegarty, 1996; Znakov, 2005; Molyako, 2007; Mahwah, 2015; Yaftian, 2015; Jaleel, 2015; Ortiz, 2016). Understanding is not only the result of thinking, but it is one of its processes (Moiseienko, 2003; Moiseienko \& Shegda, 2019), it takes an active part in solving the problem, ensures the success of its solution. Therefore, the study of the process of understanding in solving various mathematical problems is an important component of the problem of elucidating the psychological essence of creative mathematical thinking.

Today it remains actual to clarify the essence of psychological aspects of individual-personal differences in the thinking process in general and in the understanding process in particular. Regarding mathematical thinking, there is a division into «algebraists» and "geometers» in the literature. The point is that a great number of people solving a mathematical problem prefer an analytical or a visual method of interpreting the

(C) Moiseienko Lidiia \& Shehda Liubov DOI (article): https://doi.org/10.32626/2227-6246.2021-51.142-164 
DOI: https://doi.org/10.32626/2227-6246.2021-51 2021. виПуСК 51

condition and finding a solution. Many mathematicians and researchers of mathematical creativity adhere to the division into logicians and intuitionists. According to this division, logicians are mathematicians with a narrowly directed flow of thoughts which produce ideas that can be traced from a start to a positive result (thoughts lay on the surface). Intuitionists are characterized by a wide scattering of thoughts produced largely unconsciously.

Recently, scientists have turned their attention to clarifying the individual style of the activity as an integral concept that provides information about the individual-personal singularity of the activity.

M.O. Kholodna (Kholodnaya, 2002) considers that different subjects mentally «see» the same situation in different ways and, accordingly, react to it differently (evaluate, make decisions, judgments, etc.). This scientific point of view has become the foundation of the ideology of stylistic approach. A. V. Libin (Libin, 1991) emphasizes that the style is a phenomenon that has a dual nature and arises at the intersection of individuality and environment. That is the style occupies a boundary position between the individual and the environment and is both a human invention and means of any activity or activity aimed at transforming the environment (drawing style, writing style, cognition style, etc.). This creates a basis for the study of human style through the study of its individuality or through the study of the activity in the process of which this style operates.

Regarding the style of mathematical thinking V. Y. Perminov (Perminov, 1999) draws attention of scientists to two fundamentally different systems of ideas which exist in the structure of mathematical knowledge - empirical and categorical. Therefore, according to his point of view, the combination of empirical and categorical systems in the thinking of mathematicians is the basis that gives the right to differentiate their thinking about the styles. V. E. Wojciehowicz (Wojciehowicz, (c) Moiseienko Lidiia, Shehda Liubov

DOI (article): https://doi.org/10.32626/2227-6246.2021-51.142-164 
1999) identifies three factors that, in his opinion, underlie the classification of mathematical thinking of the scientists. He marks out three styles: personality of the scientist; specific properties of mathematical knowledge and socio-cultural context of the time. L. B. Sultanova (Sultanova, 1999) ascertains that implicit knowledge and intuition determine the style of mathematical thinking.

Thus, the mathematical thinking style is such combination of features that distinguishes the activity of one person from the same activity of another person in the field of mathematics; it is a holistic system of interconnected actions, by means of which a mathematical result is achieved. This system depends on objective requirements of mathematical activity and on personality traits. It includes individual application of operations, methods, intermediate goals, etc. The mathematical style is a mathematical handwriting, an individual feature of a person who solves a mathematical problem. This point of view is basic for the analysis of thinking styles of understanding process in this article.

The purpose of this article is to analyze the influence of the mathematical style of a person on understanding process of a creative mathematical problem with an emphasis on qualitative characteristics of its micro-stages: general acquaintance with the condition of the problem; division of the condition into main and secondary parts; recoding the task into «this person's language»; supplementing the text with drafts and sketches; highlighting the essence of the problem.

The task of the article is to identify thinking styles of understanding process of creative mathematical problems and describe their content; to find out the essence of the influence of mental mathematical style on this process.

\section{Research methods and techniques}

The method of research is the analysis of students' search actions during the solution of creative mathematical problems

(C) Moiseienko Lidiia \& Shehda Liubov DOI (article): https://doi.org/10.32626/2227-6246.2021-51.142-164 
DOI: https://doi.org/10.32626/2227-6246.2021-51 2021. випУСК 51

of different classes. We conducted an experimental study of creative mathematical thinking of the students, which study at Ivano-Frankivsk National Technical University of Oil and Gas. 100 students took part in the experiment.

We used a problem-based research method. It relies on the process of solving mathematical problems, which reveals patterns and advantages of mental actions in mathematical creativity in the best way (Moreno-Armella, Hegedus \& Kaput, 2008). That is, having developed a series of relevant mathematical problems, we have analyzed the process of understanding them, focusing on the study of individual differences of the students.

At first, to identify the styles of mathematical thinking of the people under study, we selected three problems and analyzed the search process in solving them. There were multifaceted tasks that contained hidden problems. The first and the third problems involved several solutions. Each of these solutions is based on various generalized schemes that reflect a certain meaning of the problem. In the process of solving these problems thinking had to rely on logical, numerical and spatial components. In addition, their solution involves conjecture, so we have taken into consideration these two components (logical and intuitive) for differentiation of mathematical thinking by styles. As a criterion for this division, we have chosen the nature of the conscious logical steps in the search process and the place and role of unconscious thinking acts. In analyzing the research activities of students, aimed at solving several special problems, three mathematical thinking styles were identified.

For further and deeper analysis of mental actions according to the selected styles of mathematical thinking, 23 series of problems were selected, so that each series can contribute to the study of a certain aspect of mathematical thinking. In total, 160 tasks have been used. All problems, regardless of the series, were divided into 4 classes: problems of finding an unknown quantity, problems of proof, problems of construction (C) Moiseienko Lidiia, Shehda Liubov

DOI (article): https://doi.org/10.32626/2227-6246.2021-51.142-164 
and heuristic problems, which are divided by the nature of the requirements. Each of 100 students solved 10 different mathematical problems (to find an unknown quantity, to prove, to construct, heuristic problems).

The tasks have been performed by each student in the presence of the experimenter. The work has been carried out individually. The student has been given the opportunity to work independently, there have been no direct instructions on how to solve it. The tasks have not been limited to a certain time.

It should be emphasized that for us understanding any problem means understanding the condition (basic structural elements, functions, connections between them), understanding what is the solution, and understanding how to achieve this solution.

\section{Results and discussions}

In our opinion, we have found three different ways to overcome each mathematical problem and have established the statistical significance of the differences between the indicators of the first, second and third groups. Thus, the mathematical thinking of the students has been divided into three styles: the differential, the integral and the differential-integral. As a result of this division, it has been found that the creative mathematical activity of almost $51 \%$ of students who participated in the experiment is subject to the differential style, almost $20 \%$ - to the integral style and almost $23 \%$ refer to the differential-integral style. The mathematical style of a small number of the students (about 6\%) could not be identified by solving these problems.

The main content of the thinking process of differential style is a detailed analysis of the problem situation in order to reduce the new problem in whole or in part to a known problem for the subject. To achieve this and from this point of view the condition of the problem is studied, and hypotheses of the solution process are produced and tested. As a result, certain

(C) Moiseienko Lidiia \& Shehda Liubov DOI (article): https://doi.org/10.32626/2227-6246.2021-51.142-164 
structural elements, their combinations, their properties motivate the subject to certain mathematical actions. They often start at random and contribute more to the study of the problem condition than to the search for a solution. The idea of a solution is not initially defined and is an amorphous formation with various variants.

This is an analytical-synthetic activity, which consists in the alternation of logically possible steps that contribute to the reduction of a new task situation to the known ones. Such activity is concretized in search of an opportunity to carry out a known mental method in new conditions. Logical steps aimed at a thorough study of the problem are supplemented by conjectures, which speed up the search.

The students with an integrated style of thinking at first have a guess without systematic mental actions. This guess often consists in reconstructing the constituent components of the problem, in abandoning the traditional vision of the problem. The search for confirmation of the guess that has arisen is carried out analytically - synthetically later, using known logical techniques. Therefore, the hypotheses that arise in the subsequent search process are aimed at confirming (or denying) assumptions, so they are related to the methods of their rationale.

Thinking activity, which is attributed to the differential-integral style, is based on both standard logical steps and innovative techniques. The search process can begin with the both guesswork and the traditional logical thinking steps. At the same time, in the process of developing one direction of the solution, another idea suddenly appears, which may even be quite distant from the first. This replacement occurs repeatedly, easily, without significant dependence on the initiated search operations. By studying the components of mathematical problem, such students activate different structural elements in different ways: some are associated with a specific operational meaning, other - with several meanings. If a «single(c) Moiseienko Lidiia, Shehda Liubov

DOI (article): https://doi.org/10.32626/2227-6246.2021-51.142-164 
operation» element gains a subjective advantage, it directs the search in a certain way which often produces a conjecture. The purpose of the following mental actions is the study of the conjecture. If this advantage is not found, the students continue to study the structural elements, linking them to different operational meanings.

The style of the mathematical thinking of the students was manifested in the self-regulation of the search mathematical process: in how the students plan their actions; to what extent they are able to take into account the conditions of the problem important for achieving the solution; what is their individual control, evaluation and correction of their own actions; as far as how they are purposeful, able to take into account changes in the mathematical situation that occur in the search process. This aspect of the stylistic differences in the creative mathematical thinking is largely expressed through the operational component, the content of which is the subject to the thinking strategies of the search process.

It should be emphasized, that individual style is not always "the best» (the most optimal, the most rational, the most effective, etc.). Use of individual style, leads more to emotional satisfaction from the activity than to the expected results. Choice of rational, but «not one's personal» style leads to degradation of emotional satisfaction.

The effectiveness of the selected groups of students, characterized by different styles of mathematical thinking, was statistically the same. Note that the students with differential and integral styles used fewer steps to solve the problems than the students with differential-integral style. However, the time, which they spent for searching for a solution, in all three cases was almost the same. The students with the differential and integral styles spent more time for considering and implementing some thinking steps while moving along their «trajectory» of finding a solution. Having outlined a way of search, they did not hurry to change it, and tried to find means for

(C) Moiseienko Lidiia \& Shehda Liubov

DOI (article): https://doi.org/10.32626/2227-6246.2021-51.142-164 
DOI: https://doi.org/10.32626/2227-6246.2021-51

2021. випУСК 51

its realization. The third group of students, who actually followed two search paths, moved faster in the direction of each of them, and easily abandoned the action plan in case it could not be implemented.

We will give a more detailed analysis of the differences in the process of understanding a mathematical problem related to the selected mathematical thinking styles.

The process of understanding a creative mathematical problem begins with a general acquaintance of the problem condition. Even at this, the very first, micro-stage, we observed differences in the search actions of the students with different styles. Because the first part of the students tried to read the task in detail from the beginning of acquaintance with the task, the second part instantly «ran» the text with their eyes (it seemed they even remembered a little), and the third part of the students read it at the usual pace. However, later it became clear that both groups clearly realized that it was a mathematical problem, they could even indicate the section of mathematics to which it should be attributed and describe its general scheme: "The problem of the motion of a boat moving in different ways.», "This is an exponential equation with a parameter» etc.

The result of the first acquaintance of the subjects with the differential-integral style of thinking was different. They confused equations with inequalities, a type of a quadrilateral, the direction of motion of two objects (towards or in the opposite direction). That is, the bearers of this style often have a rather vague idea of the content of the task at the first acquaintance with it. They clearly needed another reading of the condition, after that they easily changed the first characteristic of the problem. It is worthwhile noting that most of the students in this group answered yes to our question whether they had understood the task.

At the stage of dividing the condition of the problem into the main and secondary parts (the second micro-stage of the (C) Moiseienko Lidiia, Shehda Liubov

DOI (article): https://doi.org/10.32626/2227-6246.2021-51.142-164 
understanding the problem), the solvers distinguish what is given and what needs to be done. The first group of students paid more attention to clarification of the condition content and less to the requirements. We made this conclusion on the basis of the analysis of their statements and questions at this stage of solving. The second part of the students focuses more on the task requirements. That is, they focus their mental efforts on what needs to be found, proved, built, in the conditions proposed by the task. The main part for them is the requirement and only some parts of the condition, so they try to focus primarily on the content of the requirements for the solution. It is worth noting that this orientation occurs fairly quickly. The differential-integral style of mathematical thinking is characterized by a more or less equivalent study of the both "poles»: the condition and the requirement. At the same time they are examined alternately.

Later on the students with a differential style break down the text of the problem in detail into simple elements, differentiate them into known and unknown. They try to separate unknown elements from the context and study them by artificially including them in different connections with other elements, with existing theoretical facts (theorems, properties, etc.). This is a process of likening a new object to a known one (the third micro-stage of the understanding the problem), by comparing it with the mathematical constructions which are known to the subject, on the basis of interpretation through known mathematical techniques. This, in turn, leads to the development and testing of the hypotheses, which are mainly aimed at alternate detailed study of the structural elements of the problem. Such hypotheses are multifaceted, so they cover much more mathematical information than the one that leads to the solution. That is, when the students with this style of mathematical thinking interpret the problem into "their own" language, having found the area of the incomprehensible, they attract a wide range of analogues (mathematical problems,

(C) Moiseienko Lidiia \& Shehda Liubov DOI (article): https://doi.org/10.32626/2227-6246.2021-51.142-164 
mathematical elements, mathematical connections between elements) and try to get to know the incomprehensible.

The process of likening a new problem to a known problem occurs fairly quickly in the integrated style of thinking of the students. At the same time, the mathematical situations to which the new problem is related by the students can be quite remote. Their «own» standard arises without visible prior variation in capabilities, without many special actions aimed at studying the structural elements. Such standard arises in the form of a hypothesis that covers a number of structural elements of the problem, and further mental activity is aimed at its implementation or denial. The result of such point of view is a synthetic thinking product, which requires a detailed analysis in the future.

The bearers of the differential-integrated thinking style achieve their "own" vision of the problem by manipulating structural elements, which at one time may be a detailed examination of the known elements of the problem, and at another - the study of the idea of likening of a part of the task to the remembered standard.

It is worth mentioning that the students with the first two thinking styles, likening the new task to their standards, have a quite clear idea about them, and the students with the third style do not have such idea. At the initial stage of the solution, they do not rely on a clear idea of the standard: «As if, ..., this task would be about ...». This is the most common expression of the students with an integral-differential style of thinking at the stage of studying the problem condition.

The next micro-stage of the understanding process of the problem condition is supplementing the text with sketches. The subject with a differential style of thinking tries to study the problem more in detail, so, if it is possible, he often resorts to different illustrations. He willingly uses existing illustrations and creates his own ones. Such illustrations are studied and constructed in detail: additional constructions are gradually (C) Moiseienko Lidiia, Shehda Liubov

DOI (article): https://doi.org/10.32626/2227-6246.2021-51.142-164 
superimposed on the drawing, the nature of the relationship between the elements is studied and new structural connections are depicted. The final illustration is sufficiently examined both on the basis of information coming from the text of the problem, and on the basis of various conjectures and ideas of the solver. Further mental actions are closely related to the chosen illustration. These students use the illustrations based on existing subjective experience often while trying to identify the elements of the known task in a new one.

The hypotheses about the solution are connected with these illustrations: the content of the hypotheses is connected with the illustrations regardless of whether it is a drawing to a geometric problem or a topological scheme of an algebraic problem. The detailed examination of the "possibilities» of a scheme or a drawing turns it into an "operating» element of the problem which is not revisioned for some time. The most popular expression in this case was: "As it can be seen from the picture...»

The students with the integrated thinking style have their «own» different illustration. It's more of a scheme, without over-detailing. It should be noted that innovations are observed even in the construction of the illustrations: geometric drawings are often made in a non-traditional perspective, the texts of the problems are "equipped» with original topological images. There is a tendency to construct several illustrations of the same problem, but they are all approximations to the final illustration. "It will be even clearer», they say in this case, changing illustrations one after another. The bearers of this style rely on drawings and schemes too, however, they are not very closely attached to them. Therefore, they can generate the idea of the solution often independently of the illustration, and later they can change the illustration itself. But at the stage of studying the condition, in the process of understanding the creative mathematical problem, building an illustration is a process of deepening of the understanding of the problem for

(C) Moiseienko Lidiia \& Shehda Liubov DOI (article): https://doi.org/10.32626/2227-6246.2021-51.142-164 
them. The same applies to the process of verbalization of diagrams, graphs, drawings.

In the differential-integrated style of mathematical thinking, the subjects, trying to illustrate a new problem, build several schemes, drawings, which in the future will operate in parallel. They are different, because they are based on different personal conception of the problem, which is ambiguous, and change as if under the influence of the desire to experiment visually with the components of the problem. Although such experiments eventually reduce to a concrete idea of the problem, there are often several variants of schemes, that the subject will use while looking for a solution. Such schemes, drawings cannot be divided into correct - incorrect, exact inexact. The content of these illustrations rather demonstrate the emphasis on different elements of the problem, its various aspects, these are illustrations of different understandings of the essence of the problem.

The content of the details of the problem is clarified on the same basis as described above. The first group of students actualizes their various properties, study all possible connections between them. Gradually, the content of the problem requirement is studied more in detail. This is how the problem is reformulated, with a further emphasis on what is known to solve the reformulated problem, what still needs to be determined, how it can be defined. The second group creates new mathematical objects at the expense of different operations and uses them in the future. Actualization of knowledge and experience contributes to their creation. The problem is reformulated with the help of such newly created notions, because through their content the conditions and tasks of the problem are investigated and evaluated, which, in turn, forms an idea of the expediency of using some updated information and the content of what still needs to be obtained (the essence of tasks is formed). Both the first and the second groups in this way find for themselves the gaps in understanding the conditions of (C) Moiseienko Lidiia, Shehda Liubov

DOI (article): https://doi.org/10.32626/2227-6246.2021-51.142-164 
the problem and then try to overcome them. Such gaps - areas of misunderstanding - are localized in certain places in the content of the problem.

With a differential-integrated style of thinking, the examination of details is aimed at clarifying the conditions and requirements of the problem at the same time. And the reformulation of the problem is not clear and unique in its own way. It contains gaps that do not have a specific localization (each variant of its reformulation of the problem reveals its gaps). And since in parallel there are several variants of the problem reformulated «in their own way», then, depending on their content, gaps exist in different places. Such reformulations often concern only conditions or only requirements.

It should be noted that in general the task is presented to the subject in the form of a holistic system of mathematical objects, more precisely, in the form of several variants of the holistic system at this solution stage.

Subsequently, the condition of mathematical problem is included in the chain of student experience and the first hypothesis about the solution of the problem is sat up.

\section{Conclusions}

The style of mathematical thinking is manifested throughout the whole process of understanding a mathematical problem, at all its micro-stages. The psychological content of the mathematical thinking style consists in self-regulation of the search mathematical process; in individual control, assessment and correction of personal actions by the solver of the problem, in his purposefulness, in his ability to take into account the changes in mathematical situations, that arise in the process of studying the conditions of the problem and finding the solution. The phenomenon of mathematical style is manifested at all micro-stages of the process of understanding a mathematical problem.

(C) Moiseienko Lidiia \& Shehda Liubov DOI (article): https://doi.org/10.32626/2227-6246.2021-51.142-164 
DOI: https://doi.org/10.32626/2227-6246.2021-51 2021. випуск 51

The style of creative mathematical thinking is an individual characteristic of the student's understanding process of creative mathematical problems, it is stable in various problem situations. In the search thinking process in the field of mathematics, we can distinguish three styles that differ from each other in the nature, place and role of unconscious thinking acts.

The prospect of further research on this problem is to study the nature of impact of the determined mathematical styles on the content and effectiveness of other components of creative mathematical thinking: formation of solving idea of a mathematical problem, testing the solution.

\section{Literature}

Войцехович В. Э. Господствующие стили математического мышления. Стили в мателатике: социокультурная философия мателатики. Санкт-Петербург : РХГИ, 1999. С. 495-505.

Знаков В. В. Психология понимания: Проблемы и перспективы. Москва : Изд-во «Институт психологии РАН», 2005. 448 с.

Коваленко А. Б. Проблема розуміння в працях українських психологів. Теоретичні і прикладні проблеми психології. 2015. № 1 (36). C. 190-197.

Либин А. В. Стилевые особенности познавательных процессов и учебная деятельность. Способности и обучение. Москва : Просвещение, 1991. C. $102-115$.

Мойсеєнко Л. А. Психологія творчого математичного мислення. ІваноФранківськ : Факел, 2003. 481 с.

Мойсеєнко Л. А., Шегда Л. М Трансформація розуміння творчих математичних задач у процесі їх розв'язання. Проблели сучасної ncuхологї: Збірник наукових праць Кам'янець-Подільського національного університету імені Івана Огієнка, Інституту психологіï ім. Г. С. Костюка НАПН України / за наук. ред. С. Д. Максименка, Л. А. Онуфрієвої. Кам’янець-Подільський : Аксіома, 2019. Вип. 46. С. 289-308.

Моляко В. А. Творческая конструктология (пролегомены). Киев : Освита Украины, 2007. 388 с.

Перминов В. Я. Априорность и реальная значимость исходных представлений математики. Стили в математике: соииокультурная философия математики. Санкт-Петербург : РХГИ, 1999. С. 80-100.

(c) Moiseienko Lidiia, Shehda Liubov

DOI (article): https://doi.org/10.32626/2227-6246.2021-51.142-164 http://journals.uran.ua/index.php/2227-6246 
Пономарёв Я. А. Психология творчества. Москва : Наука, 1976. 303 с. Рубинштейн С. Л. О мышлении и путях его исследования. Москва : Изд-во АН СССР, 1958. 147 с.

Степанов С. Ю., Семенов И. Н. Методологический анализ психологических подходов к проблеме формирования творческого мышления. Философско-методологические аспекты гуманитарных наук. Москва : Политиздат, 1981. С. 69-72.

Султанова Л. Б. Роль интуиции и неявного знания в формировании стиля математического мышления. Стили в мателатике: социокультурная философия мателатики. Санкт-Петербург: РХГИ, 1999. C. $66-76$.

Теплов Б. М. Ум полководца. Проблелы индивидуальных различий. Москва : АПН РСФСР, 1961. 536 с.

Холодная М. А. Психология интеллекта. Парадоксы исследования. Санкт-Петербург : Питер, 2002. 272 с.

Fan, L., \& Zhu, Y. (2007). From convergence to divergence: the development of mathematical problem solving in research, curriculum, and classroom practice in Singapore. ZDM Mathematics Education, 39, 491-501. URL : https://doi.org/10.1007/s11858-007-0044-1.

Jaleel, S, \& Titus, B. (2015). Effectiveness of Gaming Strategy on Mathematical Creativity of Students at Secondary Level. Indian Journal of Applied Research, 5 (10), 243-245. DOI 10.15373/2249555X.

Mayer, R. E., \& Hegarty, M. (1996). The Process of Understanding Mathematical Problems. R. J. Sternberg, T. Ben-Zeev (Eds.). The nature of mathematical thinking, (pp. 29-53).

Moreno-Armella, L., Hegedus, S. J., \& Kaput, J. J. (2008). From static to dynamic mathematics: Historical and representational perspectives. Educational Studies in Mathematics, 68, 99-111. DOI 10.1007/ s10649-008-9116-6.

Ortiz, Enrique (2016). The Problem-Solving Process in a Mathematics Classroom. Transformations, 1 (1), 257-289. URL : https://nsuworks. nova.edu/transformations/vol1/iss1/1.

Salomon, Gavriel (1993). No distribution without individual's cognition: a dynamic interactional view. Distributed Cognition: Psychological and Educational Considerations, (pp. 4-128). Cambridge, UK : Cambridge University Press.

Yaftian, N. (2015). The outlook of the Mathematicians' Creative Processes. Procedia. Social and Behavioural Sciences, 191, 2515-2519. URL : https://www.journals.elsevier.com/procedia-social-and-behavioralsciences/special-issues.

(C) Moiseienko Lidiia \& Shehda Liubov

DOI (article): https://doi.org/10.32626/2227-6246.2021-51.142-164 
Zekeriya, Karadag (2009). Analyzing students' mathematical thinking in technology-supported environments. Extended abstract of candidate's thesis. Toronto. $195 \mathrm{p}$.

Ziff, P. (1972). Understanding Understanding. Ithaca - London. 146 p.

\section{References}

Voitsekhovich, V. Ye. (1999). Gospodstvuiushchiie stili matematicheskogo myshleniia [Dominant styles of mathematical thinking]. Stili $v$ matematike: sotsiokulturnaia filosofiia matematiki - Styles in Mathematics: sociocultural philosophy of mathematics. Sankt-Peterburg : RKhGI [in Russian].

Znakov, V. V. (2005). Psikhologiia ponimaniia: Problemy i perspektivy [The psychology of understanding: problems and prospects]. Moskva : Izd-vo «Institut psikhologii RAN» [in Russian].

Kovalenko, A. B. (2015). Problema rozuminnia v pratsiakh ukrainskykh psykholohiv [The problems of understanding in the works of Ukrainian psykholohigists]. Teoretychni i prykladni problemy psykholohiiTheoretical and applied problems of psychology, 1 (36), 190-197 [in Ukrainian].

Libin, A. V. (1991). Stilevyie osobennosti poznavatelnykh protsessov i uchebnaia deiatelnost [Style features of cognitive processes and educational activities] Sposobnosti i obucheniie - Abilities and training, (pp. 102-115). Moskva : Prosveshcheniie [in Russian].

Moiseienko, L. A. (2003). Psykholohiia tvorchoho matematychnoho myslennia [Psychology of creative mathematical thinking]. Ivano-Frankivsk : Fakel [in Ukrainian].

Moiseienko, L. A., \& Shehda, L. M. (2019). Transformatsiia rozuminnia tvorchykh matematychnykh zadach $\mathrm{u}$ protsesi yikh rozviazannia [Transformation of understanding of creative mathematical problems in the process of solving them]. Problemy suchasnoi psykholohii: $z b$. nauk. prats Kamianets-Podilskoho natsionalnoho universytetu imeni Ivana Ohiienka, Instytutu psykholohii imeni H. S. Kostiuka NAPN Ukrainy - Problems of Modern Psychology. Collection of research papers of Kamianets-Podilskyi National Ivan Ohiienko University, G. S. Kostiuk Institute of Psychology of the National Academy of Educational Sciences of Ukraine, 46, 289-308. Kamianets-Podilskyi : Aksioma [in Ukrainian].

Moliako, V. A. (2007). Tvorcheskaia konstruktologiia (prolegomeny) [Creative Constructology (prolegomans)]. Kiiev : Osvita Ukrainy [in Ukrainian].

(C) Moiseienko Lidiia, Shehda Liubov

DOI (article): https://doi.org/10.32626/2227-6246.2021-51.142-164 http://journals.uran.ua/index.php/2227-6246 
Perminov, V. Ya. (1999). Apriornost i realnaia znachimost iskhodnykh predstavlenii matematiki [A priory and real significance of the original concepts of mathematics]. Stili $v$ matematike: sotsiokulturnaia filosofiia matematiki - Styles in mathematics: sociocultural philosophy of mathematics, (pp. 80-100). Sankt-Peterburg : RKhGI [in Russian].

Ponomariov, Ya. A. (1976). Psikhologiia tvorchestva [Psychology of creativeness]. Moskva : Nauka [in Russian].

Rubinshtein, S. L. (1958). O myshlenii $i$ putiakh eho issledovaniia [About thinking and ways of studying it]. Moskva : Izd-vo AN SSSR [in Russian].

Stepanov, S. Yu., \& Semenov, Y. N. (1981). Metodologicheskii analiz psikhologicheskikh podkhodov $\mathrm{k}$ probleme formirovaniia tvorcheskogo myshleniia [Methodological analysis of psychological approaches to the problem of the formation of creative thinking]. Filosofskometodologicheskiie aspekty gumanitarnykh nauk - Philosophical and methodological aspects of the humanities, (pp. 69-72). Moskva : Politizdat [in Russian].

Sultanova, L. B. (1999). Rol intuitsii i neiavnogo znaniia $v$ formirovanii stilia matematicheskogo myshleniia [The role of intuition and tacit knowledge in the formation of the style of the mathematical thinking]. Stili $v$ matematike: sotsiokulturnaia filosofiia matematiki - Styles in mathematics: sociocultural philosophy of mathematics, (pp. 66-76). Sankt-Peterburg : RKhGI [in Russian].

Teplov, B. M. (1961). Um polkovodtsa [General's mind]. Problemy individualnykh razlichii - Problems of individual differences. Moskva : APN RSFSR [in Russian].

Kholodnaia, M. A. (2002). Psikhologiia intellekta. Paradoksy issledovaniia [The psychology of intelligence. Research paradoxes]. Sankt-Peterburg : Piter [in Russian].

Fan, L., \& Zhu, Y. (2007). From convergence to divergence: the development of mathematical problem solving in research, curriculum, and classroom practice in Singapore. ZDM Mathematics Education, 39, 491-501. Retrieved from https://doi.org/10.1007/s11858-0070044-1.

Jaleel, S, \& Titus, B. (2015). Effectiveness of Gaming Strategy on Mathematical Creativity of Students at Secondary Level. Indian Journal of Applied Research, 5 (10), 243-245. DOI 10.15373/2249555X.

Mayer, R. E., \& Hegarty, M. (1996). The Process of Understanding Mathematical Problems. R. J. Sternberg, T. Ben-Zeev (Eds.). The nature of mathematical thinking, (pp. 29-53).

(C) Moiseienko Lidiia \& Shehda Liubov

DOI (article): https://doi.org/10.32626/2227-6246.2021-51.142-164 
DOI: https://doi.org/10.32626/2227-6246.2021-51 2021. випуск 51

Moreno-Armella, L., Hegedus, S. J., \& Kaput, J. J. (2008). From static to dynamic mathematics: Historical and representational perspectives. Educational Studies in Mathematics, 68, 99-111. DOI 10.1007/ s10649-008-9116-6.

Ortiz, Enrique (2016). The Problem-Solving Process in a Mathematics Classroom. Transformations, 1 (1), 257-289. Retrieved from https:// nsuworks.nova.edu/transformations/vol1/iss1/1.

Salomon, Gavriel (1993). No distribution without individual's cognition: a dynamic interactional view. Distributed Cognition: Psychological and Educational Considerations, (pp. 4-128). Cambridge, UK : Cambridge University Press.

Yaftian, N. (2015). The outlook of the Mathematicians' Creative Processes. Procedia. Social and Behavioural Sciences, 191, 2515-2519. Retrieved from https://www.journals.elsevier.com/procedia-social-andbehavioral-sciences/special-issues.

Zekeriya, Karadag (2009). Analyzing students' mathematical thinking in technology-supported environments. Extended abstract of candidate's thesis. Toronto.

Ziff, P. (1972). Understanding Understanding. Ithaca - London.

\section{Мойсеєнко Лідія, Шегда Любов. Мисленнєві стилі розуміння творчих математичних задач у процесі їх розв'язування}

\section{АНОТАЦІЯ}

Проаналізовано результати досліджень творчого математичного мислення і констатовано доцільність вивчення його індивідуальних відмінностей шляхом аналізу мисленнєвих стилів розв'язування творчих математичних задач.

Mета cmammi - виокремити мисленнєві математичні стилі у студентів і проаналізувати вплив стилю на процес розуміння творчої математичної задачі.

Для виокремлення та визначення сутності мисленнєвих математичних стилів було використано метод аналізу пошукових дій суб'єктів упродовж розв'язування творчих математичних задач різних класів. У експерименті взяло участь 100 студентів технічного університету, проаналізовано 1000 процесів розв'язування математичних задач.

Результати дослідження. Констатовано, що мисленнєвий математичний стиль - цілісна система взаємопов'язаних дій, за допомогою яких досягається мисленнєвий математичний результат. Саме ия си(C) Moiseienko Lidiia, Shehda Liubov

DOI (article): https://doi.org/10.32626/2227-6246.2021-51.142-164 http://journals.uran.ua/index.php/2227-6246 
стема відрізняє діяльність у галузі математики однієї людини від такої ж діяльності іншої людини.

Авторами виокремлено три мисленнєві стилі у творчому математичному мисленні студентів: інтегральний, диференціальний, інтегрально-диференціальний.

Установлено, що мисленнєвий стиль проявляється у студентів упродовж усіх мікроетапів прочесу розуміння задачі, за допомогою процедур упізнавання старого в новому, прогнозування майбутнього структурних об'єктів задачі, об'єднання розрізнених елементів у ціле. Він $\epsilon$ стійким щодо задач різних класів.

Доведено, що різні мисленнєві математичні стилі сприяють актуалізації різних частин умови задачі, визначають різний характер дослідження структурних елементів, призводять до формування різних смислів однієї і тієї ж задачі.

Установлено, що неусвідомлені мисленнєві здогадки мають різний зміст, різну значущість у процесі розуміння математичної задачі студентами з різними стилями математичного мислення.

Висновки. Мисленнєвий математичний стиль проявляється впродовж усього процесу розуміння математичної задачі, забезпечує різний зміст пошукового процесу, спрямованого на розуміння математичної задачі.

Ключові слова: творче математичне мислення, процес розуміння математичної задачі, мисленнєві стилі математичного мислення.

\section{Мойсеенко Лидия, Шегда Любовь. Мыслительные стили понимания творческих математических задач в прочессе их решения}

\section{АННОТАЦИЯ}

Проанализированы результаты исследований творческого математического мышления и констатировано челесообразность изучения его индивидуальных отличий, используя анализ мыслительных стилей прочесса решения творческих математических задач.

Цель статьи - выделить мыслительные математические стили у студентов и проанализировать влияние стиля на процесс понимания творческой математической задачи.

Для выделения и определения сущности мыслительных математических стилей был использован метод анализа поисковых действий

(C) Moiseienko Lidiia \& Shehda Liubov DOI (article): https://doi.org/10.32626/2227-6246.2021-51.142-164 
DOI: https://doi.org/10.32626/2227-6246.2021-51 2021. виПуск 51

субъектов на протяжении решения творческих математических задач разных классов. В эксперименте приняло участие 100 студентов технического университета, проанализировано 1000 прочессов решения творческих математических задач.

Результаты исследования. Констатировано, что мыслительный математический стиль - это целостная система взаимосвязанных действий, с помощью которой достигается математический результат. Именно такая система отличает математическую деятельность одного человека от такой же деятельности другого человека.

Авторами выделено три мыслительных стиля в творческом математическом мышлении студентов: интегральный, дифференциальный, интегрально-диффреренциальный.

Установлено, что мыслительный стиль проявляется у студентов на протяжении всех микроэтапов процесса понимания задачи, с помощью процедур узнавания старого в новом, прогнозирования будущего структурных объектов, объединения разрозненных элементов в целое. Он является стойким относительно задач разных классов.

Доказано, что разные мыслительные математические стили содействуют актуализации разных частей условия задачи, определяют разный характер исследования структурных элементов, способствуют формированию разных смыслов одной и той же задачи.

Установлено, что неосознанные мыслительные догадки имеют различное содержание, различную значимость в процессе понимания математической задачи студентами с различными стилями мышления.

Выводы. Мыслительный математический стиль проявляется на протяжении всего прочесса понимания математической задачи, обеспечивает разное содержание поискового прочесса, устремленного на понимание математической задачи.

Ключевые слова: творческое математическое мышление, прочесс понимания математической задачи, мыслительные стили математического мышления.

Original manuscript received December 14, 2020 Revised manuscript accepted January 20, 2021

(C) Moiseienko Lidiia, Shehda Liubov

DOI (article): https://doi.org/10.32626/2227-6246.2021-51.142-164 http://journals.uran.ua/index.php/2227-6246 